\title{
ANALYSIS OF ASSETS OF LISTED COMPANIES IN THE TOURISM SECTOR IN CROATIA
}

\author{
Vlasta Roška ${ }^{55}$ \\ Dalija Kuvačićs6
}

https://doi.org/10.31410/itema.2018.134

\begin{abstract}
The tourism sector is a generator of growth of the Croatian economy. Natural beauty, clear sea, mountains, and endless plains are not enough for growth of the tourism sector. Today's tourists are looking for more than just natural beauty. Companies in the tourism sector need constant investments in maintaining their properties, investing and current standards improvement.

The main goal of this paper is to determine how the companies in the tourism sector, listed on the Zagreb Stock Exchange, use their assets. The analysis of the listed companies in the tourism sector is based on three indicators: Return on Assets, Total Assets Turnover, and Current Asset Turnover. These three indicators are calculated for the period of the years 2017, 2012 and 2008. The data are processed statistically with the SPSS program. The results show that a company's management was more efficient in 2017 than in 2012 or 2008 in using its assets to generate profit or revenue.
\end{abstract}

Keywords: Return on Assets (ROA), Total Assets Turnover, Current Assets Turnover

\section{INTRODUCTION}

$\mathrm{T}$ The tourism sector is a generator of growth of the Croatian economy and is, therefore, the main branch on which the state budget has relied on years. According to the information of the Croatian National Bank [1], tourist sector has realized revenue in the amount of 9.5 billion EUR in the year 2017, in the year 20126.83 billion EUR and in the year 20087.46 billion EUR. The share of travel revenue from tourism amounts to $19.6 \%$ in total GDP.

The companies listed on the Zagreb Stock Exchange in the tourism sector should lead the way for the development of tourism in Croatia. This research includes 26 companies in the tourism sector, including hotel companies, marines and camp activities. Only 26 companies have published their financial statements for all three investigated years: 2017, 2012 and 2008. The year 2017 is the last year of published financial statements and represents the latest situation, the year 2012 in Croatia is the year of the beginning of pre-bankruptcy settlements and 2008 is the first year of the world's financial crises.

The main aim of this paper is to determine how well the company's assets are being used to generate revenue or profit in the tourism sector on the Zagreb Stock Exchange. The analysis of the listed companies in the tourism sector is based on three indicators: Return on Assets (ROA), Total Assets Turnover and Current Asset Turnover. These three indicators calculated for the period of the years 2017, 2012 and 2008 in order to show how efficient was the management of a touristic company listed on the Zagreb Stock Exchange during the researched period.

\footnotetext{
${ }^{55}$ University North, Croatia, Koprivnica, Trg dr. Žarka Dolinara 1, Croatia

${ }^{56}$ Zagreb University of Applied Sciences, Croatia, Zagreb, Vrbik 8, Croatia
} 


\section{THEORETICAL BACKGROUND}

Efficiency ratios as asset turnovers and profitability ratio as the return of assets evaluate how well a company uses its assets to generate revenue or profit. "When analysts rapidly assess the financial position of a company, they first look at the two key categories of profitability and degree of indebtedness“" [2].

Efficiency or activity ratios used in this paper are total assets turnover and current assets turnover. An analysis of the property turnover "is not actually a real property turnover, but a coefficient that tells how many monetary units of total assets create cash revenue units" [3].

The total asset turnover measures the efficiency of a company's assets in generating total revenue or sales. It tells how many Croatian kuna of the total or current asset creates the amount of sales or total revenue. Return on assets (ROA) is a profitability ratio that provides information on how much profit a company is able to generate from its assets. Generally, a higher amount or ratio is favored because there is an implication that the company is efficient in generating profit or revenues. A lower ratio shows that a company is not using the assets efficiently and has internal problems.

In the Vizek research [4] the development of Croatian tourism sector during the ten years from 1997 to 2006 is analyzed. "The results of the analysis point to the conclusion that Croatian tourism shows good results in the form of a strong increase in tourism revenues, a reduction in unit labour costs, labour productivity growth, employment and GVA in the industry Hotels and restaurants. The problems of Croatian tourism are reflected in insufficient level of investment..., emphasized seasonal tourism, associated inadequate accommodation capacities and negative business results of a large part of the business Hotels and restaurants" [5].

In the Kim and Baker research [6] ratio analysis was used to examine notable financial trends within four major sectors of the hospitality industry for the period 1997-2001, namely lodging, restaurants, airlines and the amusement sector. Some of the results are:" Both ratios of profitability, net profit margin, and ROA, are significantly higher in the segment of hotels and motels than in the segment of amusement and recreational services" [7].

\section{THE GOALS, BASIS, AND HYPOTHESIS OF THE RESEARCH}

The main aim of this paper is to determine how well the company's assets are being used to generate sales or profit in the tourism sector on the Zagreb Stock Exchange. The result shows how efficient the management of a touristic company listed on the Zagreb Stock Exchange during the research period and shows if the situation today is better than in 2012 and 2008.

The research described in this paper is based on information obtained from the financial statements of 26 companies from the tourism sector listed on the Zagreb Stock Exchange in 2017, 2012 and 2008.

In the research, the following Return on Assets (ROA), Total Assets Turnover, and Current Assets Turnover were calculated according to the formulas shown in Table 1. 
Table 1: The main formulas

\begin{tabular}{|c|c|c|}
\hline Description & Numerator & Denominator \\
\hline Return on Assets & Net profit & Total Assets \\
\hline Total Assets Turnover & Total revenue & Total Assets \\
\hline Current Assets Turnover & Total revenue & Current Assets \\
\hline
\end{tabular}

The following statistical hypotheses are used for confirmation of the main aim:

The first statistical hypothesis:

H0: There is no statistically significant difference in ROA depending on which year ratio is calculated

H1: There is a statistically significant difference in ROA depending on which year ratio is calculated

The second statistical hypothesis:

H0: There is no statistically significant difference in Total Assets Turnover depending on which year ratio is calculated

H1: There is a statistically significant difference in Total Assets Turnover depending on which year ratio is calculated

The third statistical hypothesis:

H0: There is no statistically significant difference in Current Assets Turnover depending on which year ratio is calculated

H1: There is a statistically significant difference in Current Assets Turnover depending on which year ratio is calculated

For the statistical analysis, this paper uses Descriptive Analysis, a nonparametric test like the Friedman test and Wilcoxon signed-rank test. The Friedman test is the non-parametric alternative to the one-way ANOVA with repeated measuring. The non-parametric test is used because data samples are not normally distributed, and the assumption of normality is violated. Friedman test is based on mean rank, not mean value. The test compares the ranked value with expected values in a chi-square analysis.

The statistical study used the software IBM SPSS.

\section{RESEARCH RESULTS}

This research involved 26 companies which published annual reports in the years 2017, 2012 and 2008 on the Zagreb Stock Exchange. Hotels, marinas or camping activities are the main business activities of all 26 companies in this research in the tourism sector. 
Chart 1: The Group Results of the listed Companies

\section{Basic characteristic of listed companies}

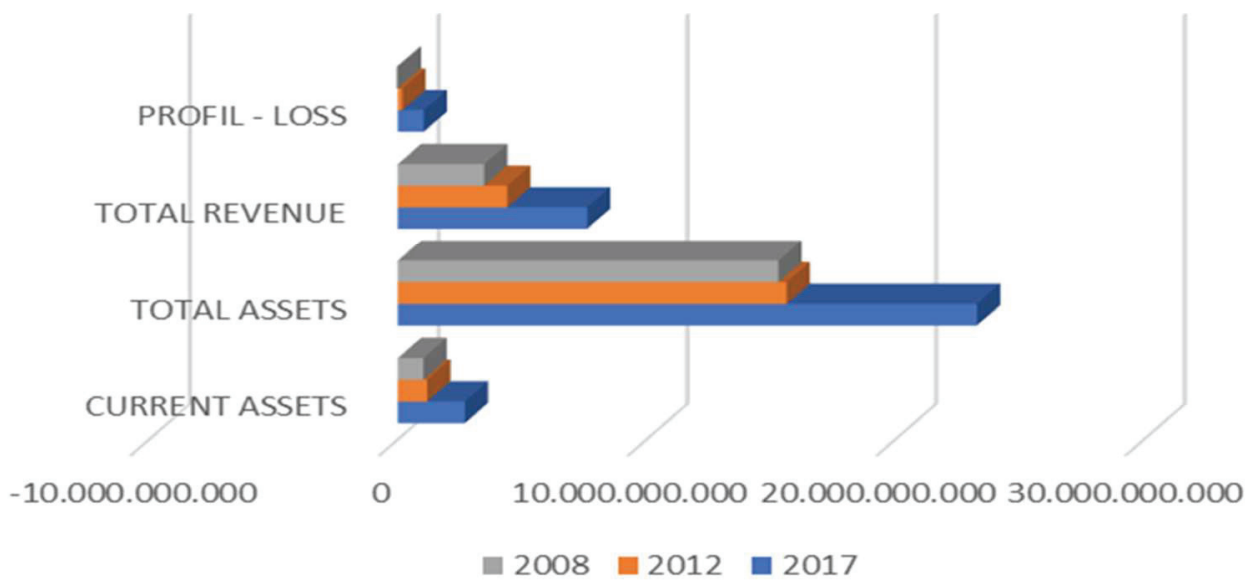

The common characteristic of the researched companies for the years 2017, 2012 and 2008 is shown in Chart 1. It is a visible trend of increase of all examined variables for every examined year, especially in 2017. Current assets of the group in 2012 are increased by $14 \%$ according to 2008 and $129 \%$ in 2017 according to 2012. Total assets of the group in 2012 are increased by $2 \%$ according to 2008 and $49 \%$ in 2017 according to 2012. Total revenue of the group in 2012 is increased by $27 \%$ according to 2008 and $73 \%$ in 2017 according to 2012 . The financial result of the group (profit minus loss) in 2008 was a loss, but in 2017 profit has increased by $474 \%$ than 2012.

Chart 2: Profit and Loss

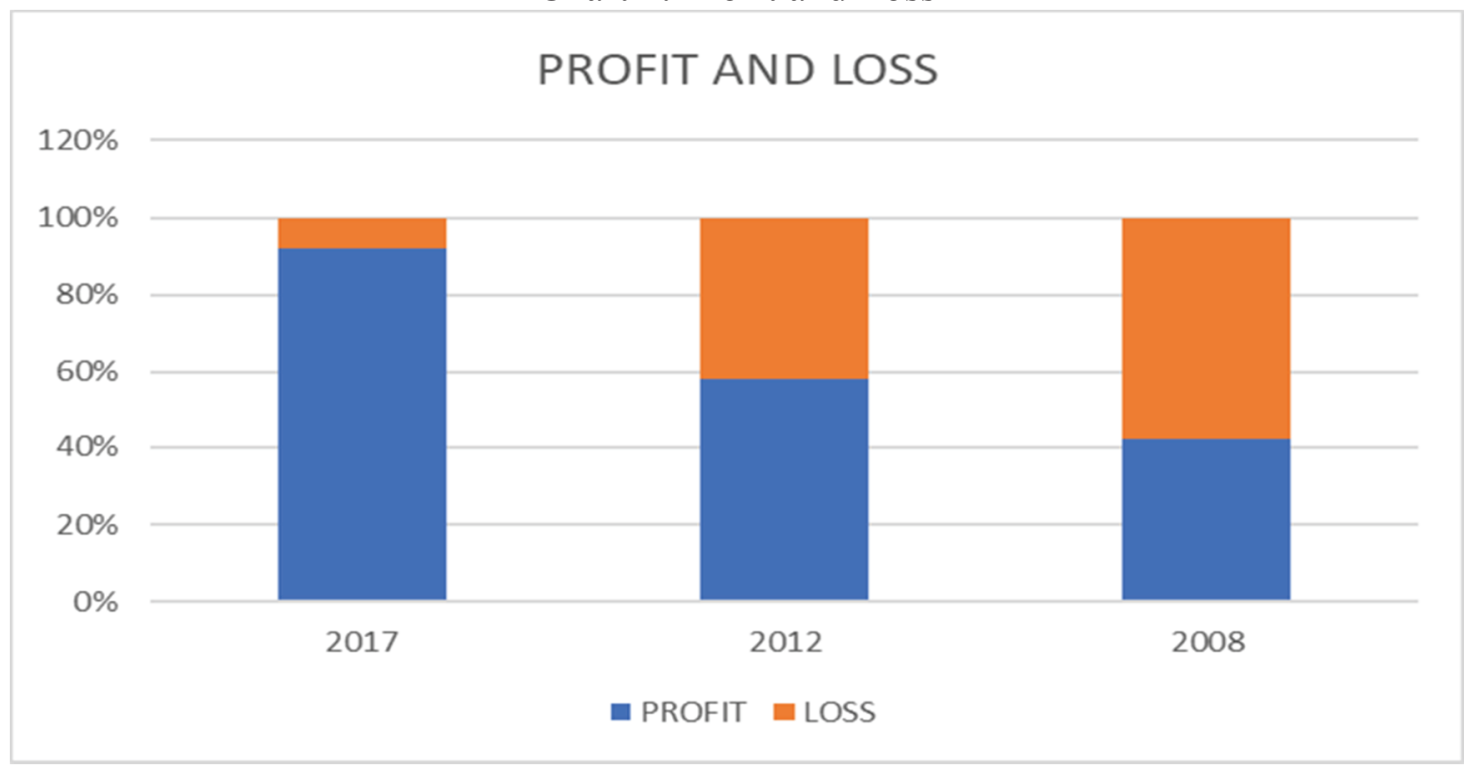

In 2017 profit was realized in $92 \%$ of companies, in 2012 in $58 \%$ and in 2008 in $42 \%$ of the companies, as shown in Chart 2. From 2012 to 2017 19\% of the companies in the group were involved in the pre-bankruptcy settlement in an attempt to save companies from bankruptcy. 
Table 2: Friedman Test for ROA

\begin{tabular}{|c|c|c|c|c|c|c|c|c|}
\hline \multicolumn{9}{|c|}{ Descriptive Statistics } \\
\hline & \multirow[b]{2}{*}{$\mathrm{N}$} & \multirow[b]{2}{*}{ Mean } & \multirow[b]{2}{*}{$\begin{array}{c}\text { Std. } \\
\text { Deviation }\end{array}$} & \multirow[b]{2}{*}{ Minimum } & \multirow[b]{2}{*}{ Maximum } & \multicolumn{3}{|c|}{ Percentiles } \\
\hline & & & & & & 25th & $\begin{array}{c}\text { 50th } \\
\text { (Median) }\end{array}$ & 75th \\
\hline ROA 2017 & 26 & 3.72 & 5.06 & -3.35 & 20.86 & 0.73 & 2.43 & 5.75 \\
\hline ROA 2012 & 26 & -0.87 & 10.72 & -46.33 & 20.06 & -2.65 & 0.93 & 3.56 \\
\hline ROA 2008 & 26 & -2.96 & 10.21 & -49.41 & 11.39 & -4.36 & -1.72 & 0.16 \\
\hline
\end{tabular}

Friedman Test
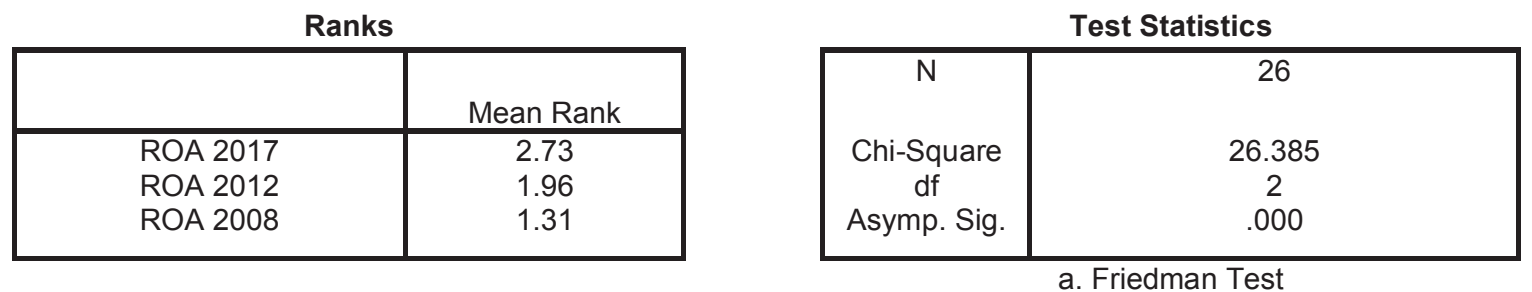

The result of the Friedman Test for ROA is shown in Table 2. There is a statistically significant difference in ROA, $\chi 2(2)=26.385, p=0.000$. Because $p<0.05$ we will reject the first null hypothesis.

Table 3: Friedman Test for Total Assets Turnover

\begin{tabular}{|c|c|c|c|c|c|c|c|c|}
\hline \multicolumn{9}{|c|}{ Descriptive Statistics } \\
\hline & $\mathrm{N}$ & Mean & $\begin{array}{c}\text { Std. } \\
\text { Devia } \\
\text { tion }\end{array}$ & Min. & Max. & 25th & \multicolumn{3}{|c|}{$\begin{array}{c}\text { P0th } \\
\text { (Median) }\end{array}$} & 75 th \\
\hline $\begin{array}{c}\text { TOTAL ASSETS } \\
\text { TURNOVER 2017 }\end{array}$ & 26 & 0.33 & 0.32 & 0.01 & 1.79 & 0.20 & 0.28 & 0.36 \\
\hline $\begin{array}{c}\text { TOTAL ASSETS } \\
\text { TURNOVER 2012 }\end{array}$ & 26 & 0.24 & 0.12 & 0.01 & 0.58 & 0.16 & 0.24 & 0.34 \\
\hline $\begin{array}{c}\text { TOTAL ASSETS } \\
\text { TURNOVER 2008 }\end{array}$ & 26 & 0.22 & 0.13 & 0.00 & 0.61 & 0.11 & 0.21 & 0.31 \\
\hline
\end{tabular}

Friedman Test

\begin{tabular}{|c|c|}
\hline & Mean Rank \\
\hline TOTAL ASSETS TURNOVER 2017 & 2.38 \\
TOTAL ASSETS TURNOVER 2012 & 2.12 \\
TOTAL ASSETS TURNOVER 2008 & 1.50 \\
\hline
\end{tabular}

\begin{tabular}{|c|c|}
\hline $\mathrm{N}$ & 26 \\
Chi-Square & 10.692 \\
$\mathrm{df}$ & 2 \\
Asymp. Sig. & .005 \\
\hline
\end{tabular}

a. Friedman Test

The result of the Friedman Test for Total Assets Turnover is shown in Table 3. There is a statistically significant difference in Total Assets Turnover depending on the year for which the ratio is calculated $\chi 2(2)=10.692, p=0.005$. Because $p<0.05$ we will reject the second null hypothesis.

Table 4: Friedman Test for Current Assets Turnover 


\begin{tabular}{|c|c|c|c|c|c|c|c|c|}
\hline \multicolumn{9}{|c|}{ Descriptive Statistics } \\
\hline & \multirow[b]{2}{*}{$\mathrm{N}$} & \multirow[b]{2}{*}{ Mean } & \multirow{2}{*}{$\begin{array}{c}\text { Std. } \\
\text { Deviation }\end{array}$} & \multirow[b]{2}{*}{ Min. } & \multirow[b]{2}{*}{ Max. } & \multicolumn{3}{|c|}{ Percentiles } \\
\hline & & & & & & 25th & $\begin{array}{c}\text { 50th } \\
\text { (Median) }\end{array}$ & 75th \\
\hline $\begin{array}{l}\text { CURRENT } \\
\text { ASSETS } \\
\text { TURNOVER } \\
2017\end{array}$ & 26 & 10.00 & 27.15 & 0.88 & 141.23 & 1.59 & 3.68 & 6.55 \\
\hline $\begin{array}{l}\text { CURRENT } \\
\text { ASSETS } \\
\text { TURNOVER } \\
2012 \\
\end{array}$ & 26 & 6.15 & 4.50 & 0.64 & 16.37 & 2.95 & 4.63 & 9.43 \\
\hline $\begin{array}{l}\text { CURRENT } \\
\text { ASSETS } \\
\text { TURNOVER } \\
2008 \\
\end{array}$ & 26 & 4.23 & 3.27 & 0.00 & 13.87 & 2.06 & 3.60 & 6.30 \\
\hline
\end{tabular}

Friedman Test

\begin{tabular}{|c|c|}
\multicolumn{2}{c}{ Ranks } \\
\begin{tabular}{|c|c|}
\hline \multicolumn{2}{|c|}{} \\
\hline CURRENT ASSETS TURNOVER 2017 & 1.92 \\
CURRENT ASSETS TURNOVER 2012 & 2.27 \\
CURRENT ASSETS TURNOVER 2008 & 1.81 \\
\hline
\end{tabular}
\end{tabular}

\begin{tabular}{|c|c|}
\hline \multicolumn{2}{|c|}{ Test Statistics $^{\mathbf{a}}$} \\
\hline $\mathrm{N}$ & 26 \\
Chi-Square & 3.00 \\
$\mathrm{df}$ & 2 \\
Asymp. Sig. & .223 \\
\hline \multicolumn{2}{|c|}{ a. Friedman Test } \\
\hline \multicolumn{2}{|c|}{}
\end{tabular}

The result of the Friedman Test for Current Assets Turnover is shown in Table 4. There is no statistically significant difference in Current Assets Turnover depending on the year for which the ratio is calculated. $\chi 2(2)=3.00, p=0.223$. Because $p>0.05$ we will accept the third null hypothesis.

Friedman Test ROA and Total Assets Turnover ratio have shown a statistically significant difference in the value of the Ratios between the years. Before continuation with Post hoc analysis with Wilcoxon signed-rank test, it is needed to conduct the Bonferroni correction. A Bonferroni adjustment of the results from the Wilcoxon test is necessary because multiple comparisons are made and there is a possibility of a Type I error that will show that a result is significant when it should not be (a Type I error). In the calculation of Bonferroni adjustment, it will take the significance level into consideration which is initially used (in this case 0.05) and divide it by the number of three tests what we are conducting. So, in this example, we have a new significance level of $0.05 / 3=0.017$. This means that if the $p$-value is larger than 0.017 we do not have a statistically significant result.

Table 5: Wilcoxon Signed Rank Tests for ROA

Test Statistics ${ }^{\mathrm{a}}$

\begin{tabular}{|c|c|c|c|}
\hline & ROA 2012 - & ROA 2008 - ROA & ROA 2008 - ROA \\
& ROA 2017 & $\mathbf{2 0 1 7}$ & $\mathbf{2 0 1 2}$ \\
\hline $\mathrm{Z}$ & $-2.993^{\mathrm{b}}$ & $-4.407^{\mathrm{b}}$ & $-2.603^{\mathrm{b}}$ \\
Asymp. Sig. (2-tailed) & .003 & .000 & .009 \\
\hline
\end{tabular}

a. Wilcoxon Signed Ranks Test

b. Based on positive ranks. 
The result of the Wilcoxon signed-rank tests for ROA is shown in Table 5. There was a statistically significant difference in ROA depending on the year $\chi^{2}(2)=26.385 \mathrm{p}=0.000$. Post hoc analysis with Wilcoxon signed-rank test was conducted, with applied Bonferroni correction, resulting in a significance level set at $p<0.017$. Median ROA for the year 2017 was 2.43 ( 0.73 to 5.74$)$, for the year 2012 it was 0.93 ( -2.65 to 3.56$)$, for 2008 it was $-1.72(-4.36$ to 0.16). However, there was a statistically significant change in ROA in 2012 vs 2017 ( $Z=-$ 2.993, $\mathrm{p}=0.003)$, ROA in 2008 vs $2017(\mathrm{Z}=-4.407 \mathrm{p}=0.000)$ and ROA in 2008 vs $2012(\mathrm{Z}=$ $-2.603, \mathrm{p}=0.009)$.

Table 6: Wilcoxon Signed Rank Tests for Total Assets Turnover

Test Statistics ${ }^{\mathrm{a}}$

\begin{tabular}{|c|c|c|c|}
\hline & $\begin{array}{c}\text { TOTAL ASSETS } \\
\text { TURNOVER 2012 - } \\
\text { TOTAL ASSETS } \\
\text { TURNOVER 2017 }\end{array}$ & $\begin{array}{c}\text { TOTAL ASSETS } \\
\text { TURNOVER 2008 - } \\
\text { TOTAL ASSETS } \\
\text { TURNOVER 2017 }\end{array}$ & $\begin{array}{c}\text { TOTAL ASSETS } \\
\text { TURNOVER 2008 - } \\
\text { TOTAL ASSETS } \\
\text { TURNOVER 2012 }\end{array}$ \\
\hline $\begin{array}{c}\text { TURymp. Sig. } \\
\text { (2-tailed) }\end{array}$ & $-2.603^{\mathrm{b}}$ & $-2.832^{\mathrm{b}}$ & $-2.400^{\mathrm{b}}$ \\
\hline
\end{tabular}

a. Wilcoxon Signed Ranks Test

b. Based on positive ranks.

The result of the Wilcoxon signed-rank test for Total Assets Turnover is shown in Table 6 . There was a statistically significant difference in Total Assets Turnover depending on the year. $\chi 2(2)=10.692, p=0.005$. Post hoc analysis with Wilcoxon signed-rank test was conducted with applied Bonferroni correction, resulting in a significance level set at $p<0.017$. Median Total Assets Turnover for the year 2017 was 0.28 (0.20 to 0.36), for the year 2012 it was 0.24 ( 0.16 to 0.34 ) and for the 2008 it was 0.21 (0.11 to 0.31$)$, respectively. There were significant differences between the Total Assets Turnover in 2012 vs $2017(Z=-2.603 p=0.009)$, between the 2008 vs $2017(Z=-2.832, p=0.005)$, and between 2008 vs $20012(Z=-2.400, p=0.016)$.

\section{CONCLUSION}

The information on ROA and Asset Turnover give a manager, investor, or analyst an idea on how efficient a company's management is at using its assets to generate income or profit. According to ROA in 2017, every kuna invested in assets earned 3.7 lipa in profit. In 2012 and 2008 ROA the trend was negative due to big losses of listed companies in the tourism sector. According to Total Assets Turnover, every kuna invested in total assets earned 0.33 kuna of total revenue in total revenue in 2017, 0.24 in 2012 and 0.21 kuna in 2008. According to Current Assets Turnover, every kuna invest in current assets earned 10.00 kuna of revenue in 2017, 6.15 kuna in 2012 and 4.23 kuna in 2008.

According to the results of this research, we can conclude that the situation in 2017 is better than in 2012 and 2008. Not only is the result of the year better, but also the use of the company's assets.

For further research, the percentage of occupancy needs to be seen, as well as the fact is it the good result of the business year or pre-bankruptcy settlement.

Natural beauty, clear sea, mountains, and endless plains are not enough for growth of the tourism sector. Calculated indicators show that a company's management was more efficient in 2017 than in 2012 or 2008 in using its assets to generate profit or revenue. Listed tourism sector 
recognizes that it needs better management of its assets in order to get better results and satisfied guests.

\section{REFERENCES}

[1] Statistic- tourism, Retrieved 21.10.2018., https://www.hnb.hr/statistika

[2] Belak, V. (2014) Analiza poslovne uspješnosti, 130 ključnih pokazatelja performance i mjerila za kontroling, RRIFPlus d.o.o, Zagreb, pp. 179

[3] Belak, V. (1995) Menadžersko računovodstvo, RRIFPlus d.o.o., Zagreb, pp. 70

[4], [5] Vizek, M. (2000) Analiza odrednica hrvatskog turističkog sektora, Privredna kretanja i ekonomska kretanja br. 114, pp.79, Retrieved 21.10.2018. on the https://hrcak.srce.hr/23671

[6], [7] Kim, W. G., Baker, A. (2005) The Professional Refereed Journal of the Association of Hospitality Financial Management Educators, Journal of Hospitality Financial Management, Volume 13, Issue 1 Article 26, pp.16-19 Retrieved 18.10.2018. https://scholarworks.umass.edu/jhfm/vol13/iss 1/26 